\title{
RANCANGAN DESAIN DATA WAREHOUSE KUNJUNGAN WISATAWAN KE BALI BAW TOUR \& TRAVEL
}

\author{
I Putu Agus Eka Pratama ${ }^{1)}$, Ni Kadek Ratna Sari ${ }^{2)}$ \\ ${ }^{1,2}$ Program Studi Teknologi Infromasi, Fakultas Teknik, Universitas Udayana \\ email: eka.pratama@unud.ac.id ${ }^{1)}$, kadekratnasari@student.unud.ac.id ${ }^{2)}$
}

\begin{abstract}
This business development in the globalized era provoked fierce competition especially with the application of it to support his daily process especially in data management, therefore, the BAW Tour \& Travel needs a system for data processing so that data can be stored and integrated with each other or what's called data warehouse and followed by other regulatory ETL, OLAP methods in analysis and quick decision-making. Using the data warehouse can figure out a spike in visitors' visits so it can predict people to be able to predict the number of guides during a month in case there's a spike that reduces anyone's denial of acceptance on the grounds of lack of a guide and to booked a motel because it's already full.
\end{abstract}

Keywords: Data Warehouse, ETL, OLAP

\section{PENDAHULUAN}

\subsection{Latar Belakang}

Bali Artha Wiguna (BAW) Tour \& Travel merupakan usaha yang bergerak di bidang pariwisata berupa pelayanan tour dan travel wisatawan domestik. BAW Tour \& Travel memiliki berbagai pelayanan sesuai dengan pilihan paket dan fasilitas yang diinginkan wisatawan. BAW Tour \&Travel menerapkan sistem operasional yang masih terbatas untuk melakukan fungsi daftar dan input. Seiring dengan perkembangan teknologi yang menggencarkan objek wisata melalui media sosial, semakin bertambah pula kunjungan wisatawan yang datang tiap tahunnya.

Data kunjungan wisatawan yang dikelola meliputi data agent, tgl in-out, hotel, guide. Data - data tersebut dikelola untuk digunakan untuk dijadikan arsip data, namun mengalami kesulitan dalam melakukan rekapan dan pengambilan keputusan. Data kunjungan wisatawan dikelola dalam file Microsoft Excel yang merupakan rekapan dari data pada saat kunjungan wisatawan. Laporan yang diperoleh dengan menggunakan perhitungan secara manual dengan formula Ms. Excel serta kebutuhan analisis multidimensi. Hal tersebut membutuhkan waktu yang cukup lama untuk mendapatkan solusi yang dapat menangani masalah dengan membangun sistem data warehouse.

\subsection{Rencana Penelitian}

Rencana pemecahan masalah yang digunakan untuk mengatasi permasalahan pada BAW Tour \& Travel dengan penerapan data warehouse menggunakan MySQL dan tools Spoon Pentaho.

\subsection{Tujuan Penelitian}

Tujuan penelitian ini dilakukan adalah untuk membuat rancangan desain data warehouse yang diharapkan dapat membantu dalam pengelolaan data tamu wisatawan pada BAW Tour \& Travel. Diharapkan kedepannya data warehouse akan banyak digunakan untuk membantu dalam pengambilan keputusan.

\subsection{Tinjauan Pustaka \\ 1.4.1 Data Warehouse}

Data warehouse merupakan sekumpulan data yang berorientasi subjek, terintegrasi, dan memiliki dimensi yang digunakan untuk manajemen pengambilan keputusan dimana jika data disimpan akan saling berelasi dan dirancang berdasarkan analisis daripada proses transaksinya. Berdasarkan pengertian tersebut, data warehouse memiliki karakteristuk sebagai berikut (Antonius, 2006).

1) Subject oriented

Data warehouse dirancang untuk memudahkan user dalam pengambilan keputusan dengan memberikan pandangan yang ringkas dan sederhana mengenai subjek tertentu. 


\section{2) Integrated}

Data warehouse dikonstruksikan dengan cara mengintegrasikan sumber data yang berbeda sehingga data yang terintegrasi menjadi konsisten dan lebih mudah untuk dipahami oleh pembuat keputusan.

3) Time - variant

Data warehouse harus bisa menghasilkan sudut pandang historis dari sebuah informasi. Rentang waktu data yang terdapat dalam data warehouse cukup luas dibandingkan dengan data transaksional.

\section{4) Non - volatile}

Data bersifat read only dan diperbaharui secara berkala yang artinya data sebelumnya tidak terhapus ketika ada data baru dimasukkan (Antonius, 2006).

\subsubsection{Data Multi Dimensi}

Pendekatan dengan data multi dimensi dapat dilihat dari beberapa sudut pandang yang berbeda. Model data multi dimensi terdiri dari entitas dimensi dan entitas fakta. Skema database berisikan sekumpulan entitas yang saling berhubungan. Sebuah data warehouse memerlukan skema yang berorientasi subjek yang dapat digunakan untuk OLAP.

Tabel fakta adalah tabel yang berisikan numerik yang berelasi dengan tabel fakta. Tabel fakta berukuran besar, memiliki jumlah baris dengan kombinasi nilai dimensi dan jumlah kolom sesuai dengan jumlah dimensi yang direpresentasikan. Data fakta cenderung stabil dan tidak berubah seiring berjalannya waktu.

Tabel dimensi adalah entitas penting yang dimiliki oleh organisasi. Dimensi akan berubah jika analisis kebutuhannya berubah. Tabel dimensi berukuran lebih kecil daripada tabel fakta dan berisi data tidak numerik. Pada konsep data warehouse, dimensi ini diibaratkan sebagai bangun ruang yang memiliki dimensi (Suzana et al, 2013).

\subsubsection{MySQL}

MySQL adalah tool yang digunakan untuk mengolah SQL (Structured Query Language). SQL merupakan bahasa yang biasa digunakan untuk mengakses baris data relasi. SQL dan MySQL mempunyai sifat khusus. MySQL merupakan software atau tool yang digunakan untuk mengolah SQL. SQL merupakan bahasanya, sedangkan MySQL merupakan alatnya. MySQL merupakan pilihan utama sebagai database yang digunakan karena menggunakan lisensi GPL dan multiplatform, sehingga tidak membutuhkan biaya dan tidak tergantung pada Linux maupun OS Windows (Hyde, 2006).

\subsubsection{Spoon Pentaho Business Intelligence}

Pentaho Data Integration (PDI) merupakan software dari Pentaho yang memberikan solusi terkait Bussiness Intelligence kepada pengguna. Pentaho memiliki kemampuan untuk membuat report, melakukan analisis data, membuat dashboard, dan mengintegrasikan data melalui proses ETL (Extraction, Transformation dan Loading). Pentaho biasa digunakan untuk migrasi data, membersihkan data, loading file ke database dalam volume yang besar (Karyono et al, 2011). Pentaho juga menyediakan graphical user interface yang memudahkan user dalam penggunaannya. Spoon, Pan, Kitchen merupakan komponen dari PDI, dimana Spoon merupakan user interface untuk membuat Transformation dan juga Job (Wibisono, 2014).

\section{METODE PENELITIAN}

\subsection{Rancangan Penelitian}

Penelitian ini dilakukan dengan metode .. dengan beberapa tahapan yang digambarkan pada Gambar 2.1.

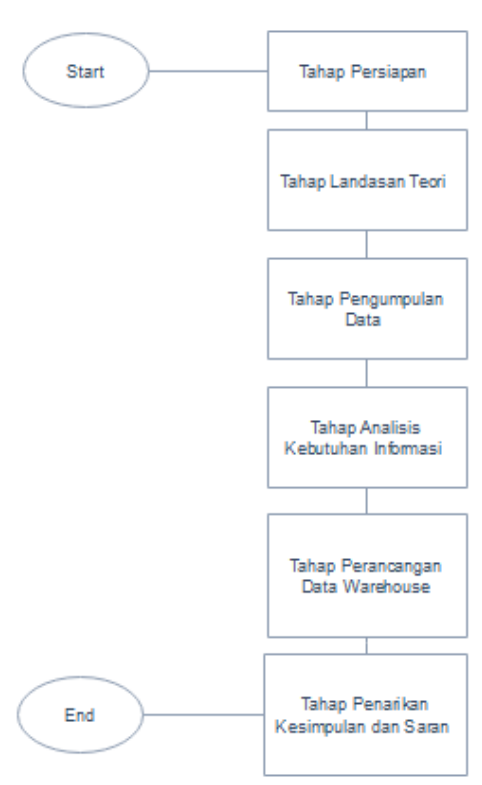

Gambar 1 Rancang Penelitian 
Pada Gambar 1 digambarkan beberapa tahapan penelitian yang akan dijelaskan berikut ini.

1) Tahap Persiapan

Tahap ini merupakan tahap awal dalam penelitian yaitu dengan menentukan latar belakang, rencanan penelitian, dan tujuan penelitian.

2) Tahap Landasan Teori

Pada tahap ini dilakukan kajian teori yang berhubungan dengan penelitian yang dilakukan, seperti teori tentang data warehouse dan review jurnal yang berkaitan dengan penelitian yang dilakukan.

3) Tahap Pengumpulan Data

Tahap ini dilakukan pengumpulan data dengan melakukan observasi

a) Wawancara

Metode wawancara, metode ini dilakukan dengan cara mengumpulkan data melalui wawancara dan tanya jawab secara langsung dengan pemilik dari BAW Tour \& Travel Bali.

b) Studi literature

Mengumpulkan referensi dari beberapa modul dan buku yang berhubungan dengan tema pariwisata

4) Tahap Analisis Kebutuhan Informasi

Setelah tahap pengumpulan data, dilakukan analisis yang menghasilkan spesifikasi kebutuhan informasi yang dibutuhkan oleh user.

5) Tahap Perancangan dan Implementasi

Pada tahap ini hal yang dilakukan adalah mendesain arsitektur fisik dan logikal data warehouse. Data yang bersumber dari database operasional akan diproses dengan konsep ETL (Extracts, Transformation, Loading).

6) Tahap Penarikan Kesimpulan dan Saran

Dari hasil perancangan dan implementasi yang telah dilakukan, maka hasil akhir dari penelitian ini merupakan penarikan kesimpulan dan saran.

\section{HASIL DAN PEMBAHASAN}

\subsection{Persiapan Sumber Data}

Pada penelitian ini, BAW Tour \& Travel belum menggunakan sistem yang sebelumnya sudah menggunakan database untuk menangani operasionalnya. Hal ini menimbulkan kesulitan dalam menganalisis data dan pengambilan keputusan. Maka dari itu, penulis membuat sebuah database yang dapat menangani operasional kantor sehingga mampu memudahkan implementasi dari data warehouse. Pada penelitian ini, database yang dibuat menggunakan DBMS MySQL.

\subsection{Rancangan Data Warehouse}

1) Analisis Kebutuhan Informasi

Analisis kebutuhan informasi merupakan tahapan menganalisis informasi menyangkut apa saja yang dibutuhkan oleh BAW Tour \& Travel untuk mendukun proses analisis, pengambilan keputusan dan evaluasi. Informasi yang dibutuhkan oleh BAW Tour \& Travel untuk dapat memprediksi peningkatan kunjungan wisatawan adalah informasi data kunjungan wisatawan pada bulan dan tahun tertentu.

\section{2) Memilih Grain}

Grain merupakan sebuah data yang dapat dianalisis dari calon fakta. Berdasarkan proses bisnisnya, peningkatan kunjungan wisatawan yang dilihat berdasarkan waktu, agent yang menggambarkan tabel fakta.

\section{3) Identifikasi Penyesuaian Dimensi}

Perancangan dimensi data warehouse yang telah dibuat dilakukan dengan membuat matriks antara grain dengan dimensi yang telah disesuaikan dengan analisis sebagai dasar perancangan data warehouse. Rancangan matriks dapat dilihat pada Tabel 1.

Tabel 1 Rancangan Matriks dan Dimensi

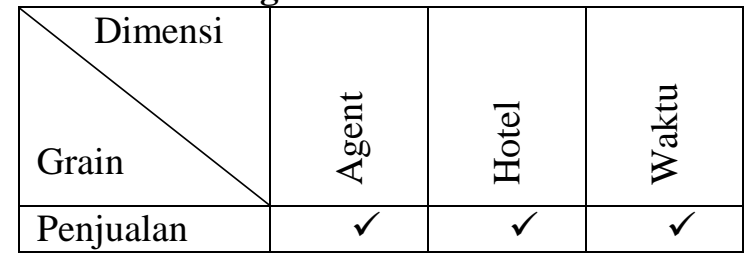

4) Memilih Fakta

Masing - masing dari fakta memiliki data yang dapat dihitung dan ditampilkan dalam berbagai bentuk seperti laporan, 
diagram dan grafik. Tabel fakta yang akan digunakan adalah data tamu dengan atribut seperti id hotel, nama agent, cek in, cek out, dan days.

\subsection{Implementasi Data Warehouse}

1) Skema Data Warehouse

Setelah melakukan tahapan analisis, memilih grain, identifikasi, dan memilih fakta yang digunakan dalam perancangan database untuk data warehouse menggunakan DBMS MySQL. Desain skema database yang dibuat dapat dilihat pada Gambar 2.

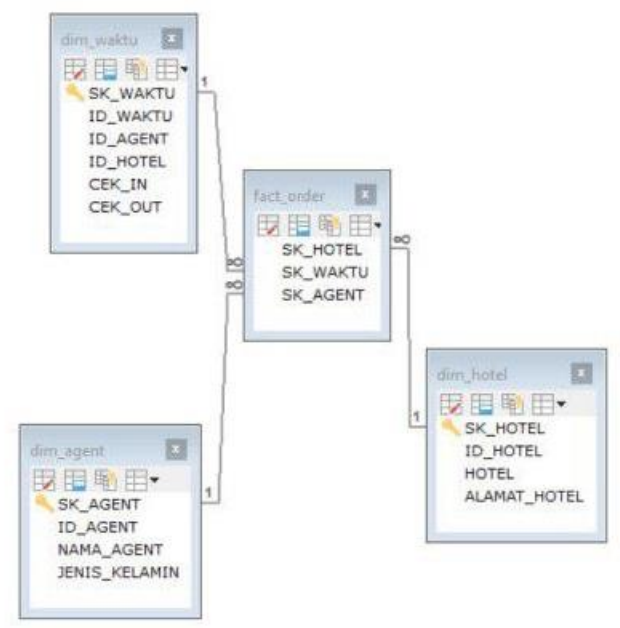

Gambar 2 Skema data warehouse BAW Tour \& Travel

\section{2) Proses ETL}

Setelah membuat database untuk data warehouse yang akan di rancang, selanjutnya adalah proses ETL yang dimulai dari database operasional ke database data warehouse menggunakan tool Spoon Pentaho Business Intelligence. Skema dari proses ETL dapat dilihat pada Gambar 3.

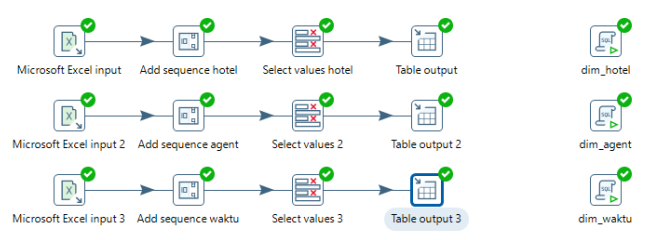

\section{Gambar 3 Proses ETL}

Gambar 3 adalah skema dari Proses ETL yang berhasil dan data tersimpan pada DBMS MySQL. Berikut merupakan tampilan data pada dim_hotel.

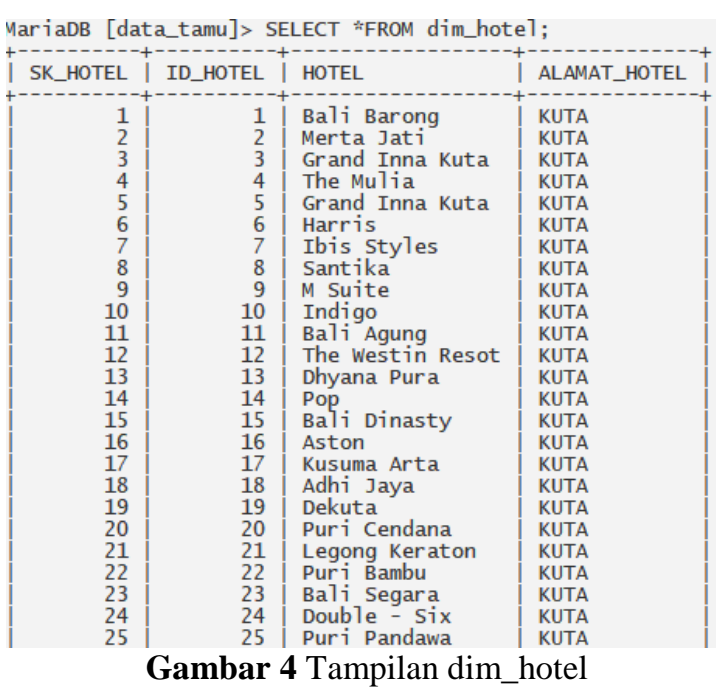

Gambar 4 merupakan tampilan data pada dim_hotel yang berisikan fields sk_hotel, id_hotel, hotel, alamat_hotel.

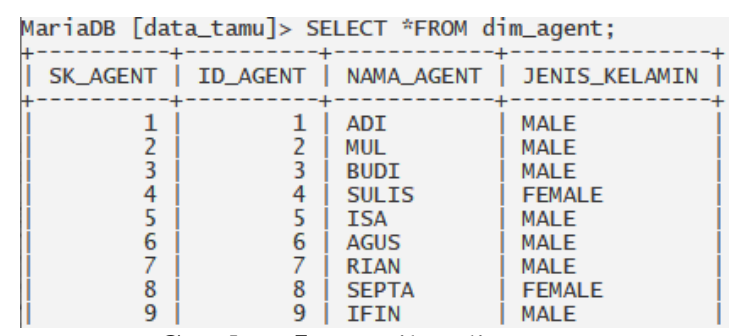

Gambar 5 Tampilan dim_agent

Gambar 5 merupakan tampilan data pada dim_agent yang berisikan fields sk_agent, id_hotel, nama_agent, jenis_kelamin.

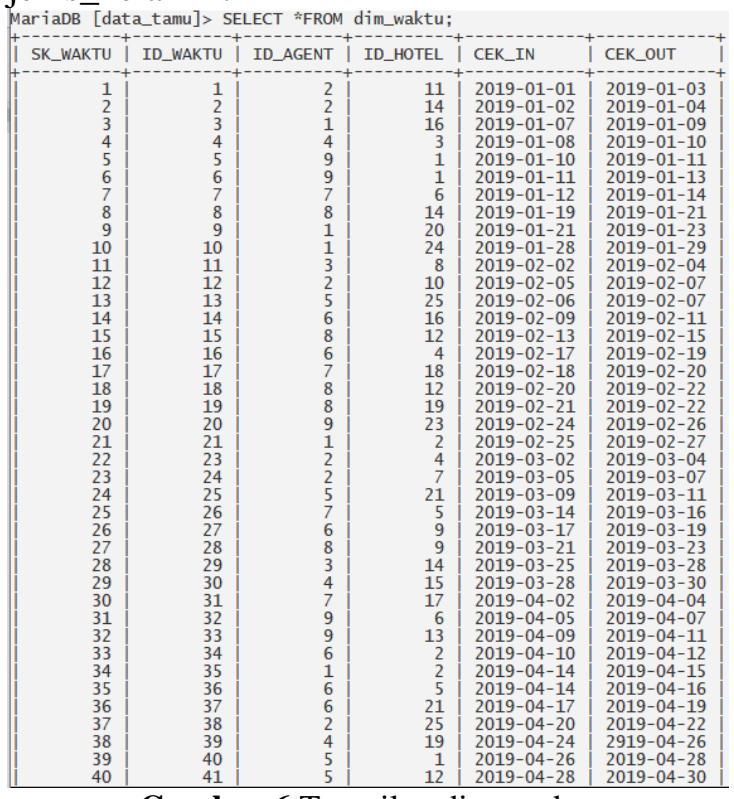

Gambar 6 Tampilan dim_waktu 
Gambar 6 merupakan tampilan data pada dim_waktu yang berisikan fields sk_waktu, id_waktu, id_agent, id_hotel, cek_in, cek_out.

\section{3) Proses OLAP}

OLAP merupakan salah satu cara untuk dapat mengolah data pada data warehouse. Informasi yang dibutuhkan oleh user dapat diambil secara detail dan rinci dari data warehouse. Informasi yang dibutuhkan oleh BAW Tour \& Travel untuk dapat melakuka prediksi peningkatan jumlah kunjungan wisatawan ke Bali adalah informasi data kunjungan wisatawan per bulannya maupun per tahun.

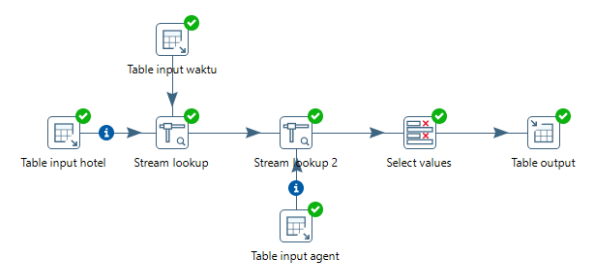

Gambar 7 Proses OLAP

Gambar 7 merupakan Proses OLAP yang berhasil disimpan dan data tersimpan pada DBMS MySQL berupa tabel fakta yang sudah terintegrasi dengan beberapa data yang ada.

\section{KESIMPULAN}

\subsection{Kesimpulan}

Berdasarkan hasil penelitian dari rancangan desain data warehouse kunjungan wisatawan ke bali pada BAW Tour \& Travel, maka dapat membuat kesimpulan sebagai berikut.

1) Rancangan desain data warehouse yang telah dibuat dapat membantu dalam proses pengambilan keputusan secara cepat bagi pemilik travel.

2) Hasil data tamu yang awalnya dilakukan secara manual, kini sudah menggunakan sistem yang akan menyimpan data pada database yang telah dibuat sehingga memudahkan untuk pemindahan data.

3) Proses integrase yang dilakukan menggunakan konsep ETL.

4) Penggunaan metode OLAP membantu dalam pengintegrasian data serta memiliki kemampuan pada system business intelligence untuk membaca data.

\subsection{Saran}

Berdasarkan hasil penelitian diatas, maka penulis dapat memberikan saran dalam pemanfaatan data warehouse dapat membantu dalam proses pengambilan keputusan ataupun analisi data suatu bisnis atau perusahaan.

\section{REFERENSI}

Antonius, H. (2006). ANALISIS DAN PERANCANGAN DATA WAREHOUSE PT CITRAKREASI MAKMUR . Jurnal BEe-SISFO Vol. 3 No. $1,12$.

Hyde, J. (2006, August). Online Analytical Processing. Retrieved from Pentaho Mondrian Documentation: https://mondrian.pentaho.com/docume ntation/olap.php

Karyono, G., Utami, E., \& Lutfi, E. (2011). PENGEMBANGAN DATA WAREHOUSE DAN ON-LINE ANALYTICAL PROCESSING (OLAP) UNTUK PENEMUAN INFORMASI DAN ANALISIS DATA . Jurnal Telematika Vol. 4 No.2, 4.

Suzana, M., Jemakmun, \& Suyanto. (2013). ANALISIS DAN PERANCANGAN DATA WAREHOUSE RUMAH SAKIT UMUM DAERAH PALEMBANG BARI . Jurnal Ilmiah Teknik Informatika Ilmu Komputer , 5.

Wibisono, Y. (2014). Pengantar Pentaho Data Integration (Kettle). Ilmu Komputer UPI, 2-17. 